\title{
Comparison of Forced-air Warming Systems and Intravenous Fluid Warmers in the Prevention of Pediatric Perioperative Hypothermia
}

\author{
Çocuklarda Perioperatif Hipoterminin Önlenmesinde Sıcak Hava Üfleme \\ Sistemleri ile Intravenöz Sıvı Isıtıcıların Karşılaştırılması

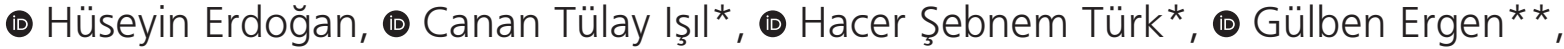 (1) Sibel Oba*}

Tunceli State Hospital, Clinic of Anesthesiology and Reanimation, Tunceli, Turkey

*Şişli Hamidiye Etfal Training and Research Hospital, Clinic of Anesthesiology and Reanimation, Istanbul, Turkey

**Tatvan State Hospital, Clinic of Anesthesiology and Reanimation, Bitlis, Turkey

\section{Abstract}

Aim: We aimed to compare the efficacy of intravenous bloodfluid warming and forced-air warming systems for the prevention of perioperative hypothermia in pediatric patients under six years of age.

Methods: Two-hundred children aged 0-6 years, who underwent elective surgery, were included in the study. Group 1 patients were warmed with forced-air warming system at the operating room. Group 2 patients were warmed with intravenous fluid and blood warming systems at the operating room. During the entire operation, heart rate, $\mathrm{SpO}_{2}$, end Tidal $\mathrm{CO}_{2}$ and esophagus temperature values were recorded at 10-minute intervals. The number of patients, who needed rescue warming, the starting time and duration of rescue warming were recorded. The duration of the anesthesia, the duration of the operation, and the time of recovery were recorded.

Results: The groups were compared in terms of mean operating room temperature and body temperature and no statistically significant difference was found between the groups. There was no statistically significant difference between the groups for additional rescue warming need and time to rescue warming. The time to recovery was longer in the patients who needed rescue warming. There was a statistically significant positive correlation between the duration of the operation and the duration of the need for rescue warming with a confidence of $99 \%$.

Conclusion: In pediatric patients, i.v. fluid warming systems are as effective as forced-air warming systems in avoiding perioperative hypothermia.

Keywords: Forced-air warming, fluid warming, pediatric patient perioperative hypothermia
Öz

Amaç: Altı yaş altı çocuk hastalarda intravenöz kan-sıvı ısıtma ve zorlamalı hava ısıtma sistemlerinin perioperatif hipoterminin önlenmesinde etkinliğini karşılaştırmayı amaçladık.

Yöntemler: Elektif cerrahi geçiren 0-6 yaş arası 200 çocuk çalışmaya alındı. Grup 1 hastaları ameliyathanede zorlamalı hava Isıtma sistemi ile Isıtıldı. Grup 2 hasta operasyon odasında intravenöz sıvı-kan ısıtma sistemleri ile ısıtıldı. Operasyon süresince Kalp atış hızı, $\mathrm{SpO}_{2}$, Tidal $\mathrm{CO}_{2}$ ve özofagus sıcaklığı değerleri 10 dakikalık aralıklarla kaydedildi. Kurtarma ısıtıcısı gereken hasta sayısı, başlangıç ısısı ve kurtarıcı Isıtıcı süresi kaydedildi. Anestezi süresi, operasyon süresi, iyileşme zamanı kaydedildi.

Bulgular: Gruplar ortalama ameliyathane sıcaklığı ve vücut ısıSı açısından karşılaştırıldı ve gruplar arasında istatistiksel olarak anlamlı bir fark bulunmadı. Ek kurtarıcı ısıtıcı ihtiyacı ve kurtarıcı ısıtıcı ihtiyacının zamanı için gruplar arasında istatistiksel olarak anlamlı bir fark yoktu. Kurtarıcı ısıtıcıya ihtiyaç duyan hastalarda iyileşme süresi uzadı ve bu ilişki istatistiksel olarak anlamlıydı. Operasyon süresi ile kurtarıcı ıııtıcı ihtiyacının süresi arasında \% 99'luk bir güven ile pozitif korelasyon vardı ve istatistiksel olarak anlamlıydı.

Sonuç: Pediyatrik hastalarda i.v. SIVI Isıtma sistemleri, perioperatif hipotermiden kaçınmak için zorlamalı hava ısıtma sistemleri kadar etkilidir.

Anahtar Sözcükler: Zorlamalı hava Isıtma, SIVı ısıtma, çocuk hasta, perioperatif hipotermi
Address for Correspondence/Yazışma Adresi: Hacer Şebnem Türk, Şi̧̧̧li Hamidiye Etfal Training and Research Hospital, Clinic of Anesthesiology and Reanimation, İstanbul, Turkey Phone: +90 5324432544 E-mail: hacersebnem@yahoo.com.tr ORCID: orcid.org/0000-0003-0225-1965 Received/Geliş Tarihi: 20 October 2018 Accepted/Kabul Tarihi: 02 December 2018

This study was presented in TARK ( $50^{\text {th }}$ National Congress of Turkish Anesthesiology and Reanimation Society) in $\mathbf{2 0 1 6}$ as an oral presentation
${ }^{-}$Copyright 2019 by The Medical Bulletin of istanbul Haseki Training and Research Hospital The Medical Bulletin of Haseki published by Galenos Yayınevi. •Telif Hakkı 2019 istanbul Haseki Eğitim ve Araştırma Hastanesi Haseki Tıp Bülteni, Galenos Yayınevi tarafından yayınlanmıștır. 


\section{Introduction}

Perioperative hypothermia is defined as a core body temperature of $<36^{\circ} \mathrm{C}$ from 1 hour before to 24 hours after the surgery. It is a common and treatable complication. General anesthesia can impair thermoregulation mechanisms by inhibiting the communication between the central nervous system and the peripheral tissues. Changes in body temperature are mostly stabilized with a standard deviation of about $0.2^{\circ} \mathrm{C}$. However, this change can reach $6^{\circ} \mathrm{C}$ in surgery patients under general anesthesia (1).

Impairments in thermoregulation can lead to severe complications such as hemostatic disorders, late recovery from anesthesia, cardiac function disorders, hepatic dysfunction, coagulation disorders, renal dysfunction, immune dysfunctions or delayed wound healing (2).

As the thermoregulation mechanisms are not fully mature in younger age groups, perioperative hypothermia is more common. The highest-risk groups are newborns and infants. Forced-air warming systems or heater blankets are commonly used for the prevention of pediatric perioperative hypothermia (3).

For adult patients, high-volume blood, blood products, and other fluids are warmed using intravenous fluid and blood warming systems. However, there is no sufficient evidence regarding the effective use of blood- and fluidwarmers for pediatric cases (4).

Researchers concerning pediatric perioperative warming methods mostly compare the efficacy of forcedair warming systems and heater blankets (5). There is no data regarding the application of intravenous blood/fluid warming systems.

For this reason, this study aims to compare intravenous warming systems with forced-air warming systems for pediatric patients aged 6 or younger.

\section{Methods}

This prospective, randomized, double-blind study was approved by the Local Ethics Committee of Şişli Etfal Training and Research Hospital (02.08.2016/1238). Written and verbal informed consent was obtained from parents of the patients. The study was conducted in the pediatric surgery clinic in a randomized and prospective manner. The study included 200 electively-operated patients aged 0-6 years and assigned American Society of Anesthesiologists (ASA) physical status class I-II.

Children without parental consent, patients with preoperative hypo/hyperthermia, patients with a risk of malignant hyperthermia, esophagus surgery candidates, low-birth-weight newborns, and prematurely born babies were excluded from the study.

The body temperatures of the patients were measured (from the ear) and recorded maximum 10 minutes before the surgery. Forced-air warming systems were used for patients with a body temperature lower than $36^{\circ} \mathrm{C}$. Patients with a body temperature of higher than $36^{\circ} \mathrm{C}$ were transferred to the operating room.

Demographic data (age, gender, weight, etc.) were recorded for each patient. The operating room temperature was kept at $22-24^{\circ} \mathrm{C}$. Randomization of the patients was performed by an independent anesthesiologist who was not in the study team.

Group $1(\mathbf{n}=\mathbf{1 0 0 )}$ : From arrival to the operating room, the patient was actively warmed with a forced-air warming system (3M ${ }^{\mathrm{TM}}$ Bair Hugger ${ }^{\mathrm{TM}}$ Warming system, 3M, Minnesota, United States) and a special blanket (3M Pediatric Underbody Blanket).

Group 2 ( $\mathbf{n = 1 0 0 ) : ~ F r o m ~ a r r i v a l ~ t o ~ t h e ~ o p e r a t i n g ~ r o o m , ~}$ the patient was actively warmed with the intravenous fluid/blood warming system (enFlow).

In the operating room, the patients were monitored with electrocardiogram (ECG) (derivation D2), oxygen saturation $\left(\mathrm{SpO}_{2}\right)$ and end-tidal carbon dioxide $(\mathrm{EtCO})$ monitoring. Heart rate $(\mathrm{HR}), \mathrm{SpO}_{2}$ and ear temperature were recorded prior to the induction and these values were accepted as the preoperative starting values. Vascular access was established with a 22-26 Gauge angiocatheter, and hydration started with intravenous isotonic fluid. All patients were anesthetized (general anesthesia) according to their planned operation. It was recorded whether the patient was anesthetized with a laryngeal mask or through intubation. The anesthesia was sustained with the minimum alveolar concentration (MAC) at 1 atmosphere with sevoflurane and a mixture of $50 \%$ $\mathrm{O}_{2} / 50 \%$ air. A thermometer was placed in the esophagus to take post-operative measurements. The $\mathrm{HR}, \mathrm{SpO}_{2}, \mathrm{EtCO}_{2}$ and esophagus temperatures were recorded at 10-minute intervals starting from the beginning of the operation. In both groups, if the patient's body temperature fell below $36^{\circ} \mathrm{C}$, a second forced-air warming system was used. The number of patients who required a rescue warmer, the time when warming was required and the duration of the requirement were recorded. Warming was terminated when the body temperatures rose above $37^{\circ} \mathrm{C}$.

The following data were also recorded: the duration of anesthesia (the time between induction and recovery), the duration of the operation (the time between skin incision and final suturing) and the duration of recovery (the time passed until a Modified Aldrete Score of 9 and higher was achieved). The patients were transferred to the post-operative recovery unit after the surgical procedure was completed and the patients recovered from the anesthesia. Body temperature of the patients was measured in the ear. A forced-air warming system (active warming) was used in patients whose body 
temperature was below $36^{\circ} \mathrm{C}$ Unwanted complications, such as bradycardia, desaturation, nausea, vomiting, skin hyperemia and hyperthermia were recorded.

\section{Statistical Analysis}

The SPSS 18 package program was used to analyze the data from the Groups 1 and 2, and to determine the differences between the different anesthesia techniques. In the study, the first step was to get to know the groups by studying the demographic variables. Subsequently, the following methods were used for the analysis of the indicated data sets: chi-square test for categorical data, Student's t-test for the continuous/ non-continuous independent variables, and Pearson's correlation coefficient for the determination of any statistically significant correlation between variables and the groups.

\section{Results}

The subjects of this study were 200 pediatric ASA I-II patients (aged 0-6 years). The study was prospective and randomized.

There was no statistically significant difference in gender, ASA, age (average) and weight (average) between the two groups (Table 1).

There was no significant difference in airway device application, duration of operation and anesthesia and recovery time between the two groups (Table 2).

There was no significant difference in average operating room temperature, average body temperature (measured at the time of entering the operation room, the beginning of anesthesia, minutes 10, 20, 30, 40, 50, 60, completion of the operation, anesthesia termination, and wake-up) (Table 3) between the two groups.

There was no significant difference in requirement of rescue warmer and the duration of the application of these warmers between the two groups (Table 4).

\begin{tabular}{|c|c|c|c|c|}
\hline & & $\begin{array}{l}\text { Group } 1 \\
(n=100)\end{array}$ & $\begin{array}{l}\text { Group } 2 \\
(n=100)\end{array}$ & $p$ \\
\hline \multirow[t]{2}{*}{ Gender } & Male & 90 & 81 & \multirow[t]{2}{*}{0.071} \\
\hline & Female & 10 & 19 & \\
\hline \multirow[t]{2}{*}{ ASA Score } & 1 & 96 & 90 & \multirow[t]{2}{*}{0.096} \\
\hline & 2 & 4 & 10 & \\
\hline \multicolumn{2}{|c|}{ Age (year) (Mean) } & 21.39 & 24.47 & 0.292 \\
\hline \multicolumn{2}{|c|}{ Weight (kg) (Mean) } & 12.95 & 13.92 & 0.332 \\
\hline \multirow[t]{4}{*}{ Diagnosis } & Phimosis & 36 & 30 & \multirow[t]{4}{*}{0.306} \\
\hline & Ingiunal Hernia & 25 & 23 & \\
\hline & Undescended testis & 14 & 10 & \\
\hline & Other & 25 & 37 & \\
\hline
\end{tabular}

When the correlation between the duration of operation and need for rescue warmers was tested, it was found that increased operative time was associated with the need for rescue warmer $(p=0.004)$ (Tables $5-6)$.

When the correlation between the duration of recovery from anesthesia and the need for rescue warmers was tested, it was found that the recovery time increased for patients who required rescue warmer $(p=0.017)$ (Tables 7-8).

$\mathrm{EtCO}_{2}, \mathrm{HR}$ and $\mathrm{SpO}_{2}$ values that were measured at the beginning of anesthesia, on minutes 10, 20, 30, $40,50,60$, completion of the operation, and anesthesia termination were compared and it was determined that there were no statistically significant difference.

\begin{tabular}{|l|l|l|l|l|}
\hline \multicolumn{4}{|l|}{ Table 2. Type of airway and Durations } \\
\hline \multicolumn{2}{|l|}{} & $\begin{array}{l}\text { Group 1 } \\
(\mathbf{n = 1 0 0 )}\end{array}$ & $\begin{array}{l}\text { Group 2 } \\
(\mathbf{n}=100)\end{array}$ & $\mathbf{p}$ \\
\hline \multirow{2}{*}{ Type of airway } & Entubation & 11 & 21 & \multirow{2}{*}{0.054} \\
\cline { 2 - 5 } & LMA & 89 & 79 & \\
\hline $\begin{array}{l}\text { Duration of operation (minutes) } \\
\text { (mean) }\end{array}$ & 42.37 & 45.16 & 0.435 \\
\hline $\begin{array}{l}\text { Duration of ansthesia (minutes) } \\
\text { (mean) }\end{array}$ & 54.92 & 56.13 & 0.744 \\
\hline $\begin{array}{l}\text { Duration of recovery (minutes) } \\
\text { (mean) }\end{array}$ & 5.66 & 6.11 & 0.066 \\
\hline LMA: Laryngeal mask airway & & & \\
\hline
\end{tabular}

\begin{tabular}{|c|c|c|c|}
\hline & $\begin{array}{l}\text { Group } 1 \\
(n=100) \\
\text { (Mean) }\end{array}$ & $\begin{array}{l}\text { Group } 2 \\
(n=100) \\
\text { (Mean) }\end{array}$ & p \\
\hline Room temperature $\left(\mathrm{C}^{\circ}\right)$ & 23.86 & 23.86 & 0.984 \\
\hline Entrance to operation room $\left(\mathrm{C}^{\circ}\right)$ & 36.52 & 36.54 & 0.657 \\
\hline Beginning of anesthesia $\left(\mathrm{C}^{\circ}\right)$ & 36.45 & 36.45 & 1.000 \\
\hline $10^{\text {th }}$ minutes $\left(C^{\circ}\right)$ & 36.33 & 36.31 & 0.590 \\
\hline $20^{\text {th }}$ minutes $\left(\mathrm{C}^{\circ}\right)$ & 36.21 & 36.20 & 0.803 \\
\hline $30^{\text {th }}$ minutes $\left(C^{\circ}\right)$ & 36.21 & 36.16 & 0.331 \\
\hline $40^{\text {th }}$ minutes $\left(C^{\circ}\right)$ & 36.19 & 36.16 & 0.598 \\
\hline $50^{\text {th }}$ minutes $\left(C^{\circ}\right)$ & 36.26 & 36.20 & 0.455 \\
\hline $60^{\text {th }}$ minutes $\left(\mathrm{C}^{\circ}\right)$ & 36.33 & 36.18 & 0.241 \\
\hline End of surgery $\left(\mathrm{C}^{\circ}\right)$ & 36.24 & 36.19 & 0.138 \\
\hline End of anesthesia $\left(\mathrm{C}^{\circ}\right)$ & 36.24 & 36.19 & 0.171 \\
\hline Arousal $\left(\mathrm{C}^{\circ}\right)$ (mean) & 36.33 & 36.25 & 0.014 \\
\hline
\end{tabular}

\begin{tabular}{|l|l|l|l|l|}
\hline \multicolumn{6}{|l|}{ Table 4. Rescue warming requirement and duration } \\
\hline \multicolumn{2}{|c|}{} & Group 1 & Group 2 & p \\
\hline Rescue warming & Yes & 19 & 21 & \multirow{2}{*}{0.724} \\
\cline { 2 - 5 } & No & 81 & 79 & \\
\hline $\begin{array}{l}\text { Duration of rescue warming } \\
\text { (minutes) (Mean) }\end{array}$ & 4.00 & 5.09 & 0.466 \\
\hline
\end{tabular}


When the changes in the body temperatures were compared in-group, it was observed that the following changes were statistically significant: between minute 40 and minute 50, minute 50 and minute 60 and between the beginning and the termination of the anesthesia.

When the changes in HR were compared in-group, it was observed that the following changes were significant: between the beginning of anesthesia and minute 10, and between minute 30 and minute 40 . When the change in $\mathrm{EtCO}_{2}$ monitoring was compared in-group, it was determined that the difference between the beginning

\begin{tabular}{|l|l|l|l|l|l|}
\hline \multicolumn{6}{|c|}{ Table 5. Rescue warming need- duration of operation } \\
\hline \multirow{2}{*}{} & $\begin{array}{l}\text { Rescue } \\
\text { warming need }\end{array}$ & - & Mean & SD & $\begin{array}{l}\text { SE } \\
\text { (Mean) }\end{array}$ \\
\hline $\begin{array}{l}\text { Operation } \\
\text { duration }\end{array}$ & Yes & 40 & 55.83 & 29.464 & 4.659 \\
\cline { 2 - 6 } & No & 160 & 40.75 & 23.112 & 1.827 \\
\hline SD: Standard deviation, SE: Standard error \\
\hline
\end{tabular}

and termination of anesthesia was significant. It was observed that this difference was 4 units.

When the changes in $\mathrm{SPO}_{2}$ values were compared in-group, it was observed that the change between the beginning of anesthesia and minute 10 was significant.

There was a statistically significant correlation with $99 \%$ confidence between ambient temperature and duration of rescue warmer requirement. There was also a significant correlation between duration of the operation and duration of need for rescue warmers (99\% confidence).

None of the patients had complications such as shivering, nausea-vomiting, or hyperthermia.

\section{Discussion}

In this study, we aimed to compare two routinely applied hypothermia prevention methods (forced-air warming and i.v. blood/fluid warming systems): primarily regarding the maintenance of normothermia, the requirement for and the duration of a rescue warmer; and

\begin{tabular}{|c|c|c|c|c|c|c|c|c|c|c|}
\hline & \multirow[b]{2}{*}{$\mathbf{F}$} & \multicolumn{2}{|c|}{$\begin{array}{l}\text { Levene's test } \\
\text { for equality of } \\
\text { variances }\end{array}$} & \multicolumn{3}{|c|}{ t-test for equality of means } & \multicolumn{4}{|c|}{$95 \%$ Confidence interval of the difference } \\
\hline & & Sig. & $\mathbf{T}$ & df & $\begin{array}{l}\text { Sig } \\
\text { (2-tailed) }\end{array}$ & $\begin{array}{l}\text { Mean } \\
\text { difference }\end{array}$ & SE difference & Lower & Upper & \\
\hline $\begin{array}{l}\text { Operation } \\
\text { Duration }\end{array}$ & $\begin{array}{l}\text { Equal variances } \\
\text { assumed } \\
\text { Equal variances } \\
\text { not assumed }\end{array}$ & 10.385 & 0.001 & 3.482 & 198 & 0.001 & 15.075 & 4.330 & 6.536 & 23.614 \\
\hline - & - & - & - & 3.012 & 51.621 & 0.004 & 15.075 & 5.004 & 5.032 & 25.118 \\
\hline
\end{tabular}

\begin{tabular}{|c|c|c|c|c|c|}
\hline \multicolumn{2}{|c|}{ Additional heater needs } & \multirow{2}{*}{$\begin{array}{l}\mathbf{n} \\
40 \\
\end{array}$} & \multirow{2}{*}{$\begin{array}{l}\text { Mean } \\
6.73 \\
\end{array}$} & \multirow{2}{*}{\begin{tabular}{|l|} 
SD \\
2.602 \\
\end{tabular}} & \multirow{2}{*}{$\begin{array}{l}\text { SE (Mean) } \\
0.411\end{array}$} \\
\hline Recovery time & Yes & & & & \\
\hline & No & 160 & 5.68 & 1.367 & 0.108 \\
\hline
\end{tabular}

\begin{tabular}{|c|c|c|c|c|c|c|c|c|c|c|}
\hline & \multirow[b]{2}{*}{$\mathbf{F}$} & \multicolumn{2}{|c|}{$\begin{array}{l}\text { Levene's Test } \\
\text { for equality of } \\
\text { variances }\end{array}$} & \multicolumn{4}{|c|}{ t-test for equality of means } & \multicolumn{3}{|c|}{$\begin{array}{l}95 \% \text { Confidence interval of the } \\
\text { difference }\end{array}$} \\
\hline & & Sig. & $\mathbf{T}$ & df & $\begin{array}{l}\text { Sig } \\
\text { (2-tailed) }\end{array}$ & $\begin{array}{l}\text { Mean } \\
\text { difference }\end{array}$ & $\begin{array}{l}\text { SE } \\
\text { difference }\end{array}$ & Lower & Upper & \\
\hline \multirow{2}{*}{$\begin{array}{l}\text { Operation } \\
\text { Duration }\end{array}$} & \begin{tabular}{|l} 
Equal \\
variances \\
assumed
\end{tabular} & \multirow{2}{*}{20.739} & \multirow{2}{*}{0.000} & \multirow{2}{*}{3.528} & \multirow{2}{*}{198} & \multirow{2}{*}{0.001} & \multirow{2}{*}{1.050} & \multirow{2}{*}{0.298} & \multirow{2}{*}{0.463} & \multirow{2}{*}{1.637} \\
\hline & \begin{tabular}{|l|} 
Equal \\
variances not \\
assumed
\end{tabular} & & & & & & & & & \\
\hline- & - & - & - & 2.469 & 44.517 & 0.017 & 1.050 & 0.425 & 0.193 & 1.907 \\
\hline
\end{tabular}


secondarily regarding their hemodynamic, respiratory and recovery (from anesthesia) effects. Both methods were successful in preventing hypothermia and there was no superiority for one over the other.

Under normal conditions, the body core temperature is regulated by the hypothalamus. The regular body temperature is $37^{\circ} \mathrm{C}$ and thermoregulatory mechanisms maintain this temperature with a standard deviation of about $0.2^{\circ} \mathrm{C}$. The production and distribution of heat are adjusted to maintain a stable body temperature. Intravenous and inhalation anesthetics have depressant effects on the hypothalamus leading to elevated threshold for heat response as well as diminished threshold for cold response, thus, widening the the normal interthreshold range from $0.2^{\circ} \mathrm{C}$ to $4^{\circ} \mathrm{C}$. In addition, the patient lose body heat as a result of remaining naked and still in the cold operating room conditions, breathing cold gases and losing heat through the body cavities $(6,7)$.

The most important risk groups for perioperative hyperthermia are the acetylsalicylic acid (ASA) III-IV patient group, elderly and pediatric patients (especially newborns). The other predictive factors are the type and duration of the operation, ambient temperature, initial body temperature, the amount of fluid/blood used during the operation and the duration of mechanical ventilation $(1,2)$. For these reasons, we chose our subjects from similar surgery groups. Indeed, the statistical analysis revealed that the groups were similar for age, duration of operation and duration of anesthesia. It was made sure that preoperative body temperature of the patients was $36^{\circ} \mathrm{C}$. In our study, we have found that the need for warming increases with increased duration of the operation.

Beedle et al. (8) have found the incidence of pediatric perioperative hyperthermia to be $16.3 \%$ and that this rate can fall to $1.84 \%$ with an attentive perioperative care (that is based on the guidelines).

The generally suggested operating room temperature is $20-23.9^{\circ} \mathrm{C}$, but it is around $23-24^{\circ} \mathrm{C}$ for pediatric cases $(2,8)$. This value was maintained for all operations performed in this study. There was no significant difference between the groups regarding changes in ambient temperature. We have determined a correlation between changes in ambient temperature and requirement of a rescue warmer. A decrease in ambient temperature increased the requirement of rescue warming.

The body temperature must be perioperatively monitored in long operations and among patients in the high-risk group. The most valuable measurements are those taken from the lower end of the esophagus (9). In this study, the lower end of the esophagus was the site for core temperature mesurement.

It is also critical to prevent the complications associated with perioperative hypothermia. The cardiovascular complications include tachycardia, increased arterial blood pressure, increased cardiac afterload and increased myocardial oxygen consumption. If the decrease in the body temperature continues, the patient may develop bradycardia, myocardial depression, hypotension and hypovolemia (10). We recorded the HR values in our study. There was no difference in HR measurements between the groups at any time. We believe that the absence of hypothermic cardiovascular complications can be explained by the fact that all patients were normothermic at the beginning of the operation.

Respiratory rate increases through central stimulation in the initial phases of hypothermia. The decreasing body temperature, combined with the decreased respiration and tidal volume, leads to respiratory depression (10). Our study included $\mathrm{SPO}_{2}$ and $\mathrm{EtCO}_{2}$ measurements. The changes were not found to be significant. However, if there is controlled mechanical ventilation together with general anesthesia, it is not possible to recognize and evaluate some hypothermic complications (such as hypoventilation or apnea).

Hypothermia under general anesthesia extends the duration of action of hypnotic drugs and neuromuscular blockers. This extends the recovery time from the anesthesia $(1,9)$. There was no statistically significant difference in recovery time between the groups in our study. However, the recovery time increased in patients who required rescue warming.

Active warming systems are used for the prevention of perioperative hypothermia. The most preferred ones are resistive and forced-air warming systems. As the resistive systems have a high risk of hyperthermia or burns, forcedair warming methods have become more prominent $(4,11)$.

Forced-air warming systems were also preferred as relief warmers in the cases where normothermia could not be provided despite the chosen warming method.

Previous studies have compared the forced-air warming blankets with other warming blankets peri- or post-operatively among pediatric patients. They have found that forced-air ventilators were more effective and the body temperatures were more stable. There were fewer cases of shivering or feeling cold $(3,5,12,13)$.

Blood/fluid warmers -another active warming technique-, are found to be insufficient in perioperative cases if the infusion amount is less than a liter of fluid per hour (14). The evidence strongly indicates that warming the body fluids with blood/fluid warmers can prevent 
perioperative hypothermia and the related complications among adult patients (15).

There is not enough research regarding the use of blood/fluid warmers in pediatric patients. In the last few years, i.v. fluid warming systems with a low volume priming of less than $4 \mathrm{~mL}$ and having minimal viscosity have become available. These can raise the body temperature quickly to $40^{\circ} \mathrm{C}(16)$. These systems have been brought pediatric applications to attention.

In their study including 8 pediatric post-trauma care patients, Bernardo et al. (17) indicated that they did not find a significant difference in the heat-loss prevention results between peripheral forced-air warming systems and fluid warmers. Serour et al. (18) have shown that the warming of the body fluids by placing the i.v. tubing under a warming mattress was effective in preventing hypothermia in abdominal surgery. In his review regarding perioperative heat management, Torossian (19) reported that the combined application of i.v. fluid warmers and forced-air warming systems was the most effective method.

There have been studies comparing forced-air warming systems with fluid warming systems in adult patients and reporting that the incidence of hypothermia decreased when the two methods are combined, as well as those reporting no significant differences between the two methods $(20,21)$.

There was no statistically significant difference in the body temperature measurements between the two groups in our study. The minimal temperature change may be due to the initial normothermia or the warming techniques included in the study. The reason for the changes after minute 40 may be due to the prolonged operative durations. The rate of requirement of a rescue warmer was $21 \%$ for the i.v. fluid warmer group and $19 \%$ for the forced-air warming system group. The duration of requirement of a rescue warmer was similar for both groups and the duration was short (4-5 minutes)

\section{Study Limitations}

The limitations of our study include the wide range of age and the high ASA scores of the subjects and prolonged operative durations.

\section{Conclusion}

To conclude, the duration of the operation and the ambient temperature are variables that are correlated with the incidence of hypothermia. Intravenous fluid warming systems are as effective as forced-air warming systems in preventing perioperative hypothermia in pediatric cases.

\section{Acknowledgements}

The authors thank all the members of the pediatric surgery team for their support.

\section{Authorship Contributions}

Surgical and Medical Practices: H.E., C.T.I., H.S..T., G.E. Concept: H.E., C.T.I., H.Ş.T., S.O. Design: H.E., C.T.I., H.Ş.T., G.E., S.O. Data Collection or Processing: H.E., C.T.I., H.S..T. Analysis or Interpretation: H.E., C.T.I., H.Ş.T., S.O. Literature Search: H.E., C.T.I., H.S.T., S.O. Writing: H.E., C.T.I., H.S..T.

Conflict of Interest: No conflict of interest was declared by the authors.

Financial Disclosure: The authors declared that this study received no financial support.

\section{References}

1. Bindu B, Bindra A, Rath $G$. Temperature management under general anesthesia: Compulsion or option. J Anaesthesiol Clin Pharmacol 2017;33:306-16.

2. Iden T, Höcker J. Prevention of Perioperative Hypothermia Guidelines for Daily Clinical Practice.Anasthesiol Intensivmed Notfallmed Schmerzther 2017;52:554-62.

3. Witt L, Dennhardt N, Eich C, et al. Prevention of intraoperative hypothermia in neonates and infants: results of a prospective multicenter observational study with a new forced-air warming system with increased warm airflow. Paediatr Anaesth 2013;23:469-74.

4. John M, Ford J, Harper M. Peri-operative warming devices: performance and clinical application. Anaesthesia 2014;69:623-38.

5. Triffterer L, Marhofer P, Sulyok I, et al. Forced-Air Warming During Pediatric Surgery: A Randomized Comparison of a Compressible with a Noncompressible Warming System. Anesth Analg 2016;122:219-25.

6. Sessler DI. Thermoregulatory defense mechanisms. Crit Care Med 2009;37(7 Supl):203-10.

7. Sessler DI. Perianesthetic thermoregulation and heat balance in humans. FASEB J 1993;7: 638-44.

8. Beedle SE, Phillips A, Wiggins $S$, et al. Preventing Unplanned Perioperative Hypothermia in Children. AORN J 2017;105:17083.

9. Hart SR, Bordes B, Hart J, et al. Unintended perioperative hypothermia. Ochsner J 2011;1:259-70.

10. White FN. A comparative physiological approach to hypothermia. J Thorac Cardiovasc Surg 1981;82:821-31.

11. Cassey J, Armstrong P, Smith GE, et al. The safety and effectiveness of a modişed convection heating system for children during anesthesia. Paediatr Anaesth 2006;16:654-62.

12. Liu X, Shi Y, Ren $C$, et al. Effect of an electric blanket plus a forced-air warming system for children with postoperative hypothermia: A randomized controlled trial. Medicine (Baltimore) 2017;96:e7389. 
13. Guvakov DV, Cheung AT, Weiss SJ, et al. Effectiveness of forced air warming after pediatric cardiac surgery employing hypothermic circulatory arrest without cardiopulmonary bypass. J Clin Anesth 2000;12:519-24.

14. Barthel ER, Pierce JR. Steady-state and time-dependent thermodynamic modeling of the effect of intravenous infusion of warm and cold fluids. J Trauma Acute Care Surg 2012;72:1590-600.

15. Campbell G, Alderson $P$, Smith $A F$, et al. Warming of intravenous and irrigation fluids for preventing inadvertent perioperative hypothermia. Cochrane Database Syst Rev 2015;4:CD009891.

16. Kim HJ, Yoo SM, Jung JS, et al. The laboratory performance of the enFLOW $\left({ }^{\circledR}\right)$, buddy lite $\left({ }^{\mathrm{T} M}\right)$ and ThermoSens $\left({ }^{\circledR}\right)$ fluid warmers. Anaesthesia 2015;70:205-8.

17. Bernardo LM, Gardner MJ, Lucke J, et al. The effects of core and peripheral warming methods on temperature and physiologic variables in injured children. Pediatr Emerg Care 2001;17:138-42.

18. Serour F, Weissenberg M, Boaz M, et al. Intravenous fluids warming by mattress is simple and efficient during pediatric surgery. Acta Anaesthesiol Scand 2002;46:80-4.

19. Torossian A. Perioperative thermal management in children.Anasthesiol Intensivmed Notfallmed Schmerzther 2013;48:278-80.

20. Cobb B, Cho Y, Hilton G, et al. Active Warming Utilizing Combined IV Fluid and Forced-Air Warming Decreases Hypothermia and Improves Maternal Comfort During Cesarean Delivery: A Randomized Control Trial.Anesth Analg 2016;122:1490-7.

21. Zhao J, Luo $A L, X u L$, et al. Forced-air warming and fluid warming minimize core hypothermia during abdominal surgery. Chin Med Sci J 2005;20:261-4. 